\title{
LOST IN TRANSLATION. IRONÍA CLÁSICA, ROMÁNTICA Y POSTMODERNA
}

\author{
LOST IN TRANSLATION. CLASSIC, ROMANTIC AND \\ POSTMODERN IRONY
}

David Sánchez Usanos

Universidad Autónoma de Madrid

\section{ABSTRACT}

This article explores the different uses of «irony» by representaive authors of different periods of intelectual history and thinks about the polysemy of the term and its philosophical implications. In particular we can see a displacement in its rtheorical use that turns postmodern irony into a conservative device in terms of social order.

Key words: irony, Socrates, Søren Kierkegaard, Friedrich Schlegel, Paul de Man, David Foster Wallace, Richard Rorty, Postmodernity.

\section{RESUMEN}

En el texto se atiende a los diferentes usos de «ironía» por parte de autores representativos de distintas épocas del pensamiento y se reflexiona acerca de la polisemia del término y sus implicaciones filosóficas. Concretamente se observa un desplazamiento en el uso retórico 
que convierte a la ironía postmoderna en un recurso fundamentalmente conservador del orden social.

Palabras clave: ironía, Sócrates, Søren Kierkegaard, Friedrich Schlegel, Paul de Man, David Foster Wallace, Richard Rorty, postmodernidad

Fecha de recepción: 13 de noviembre de 2021.

Fecha de aceptación: 26 de noviembre de 2021.

Cómo citar: Sánchez Usanos, David (2021): «Lost in translation. Ironía clásica, romántica y postmoderna», en Actio Nova: Revista de Teoría de la Literatura y Literatura Comparada, monográfico 5: 223-242.

DOI: https://doi.org/10.15366/actionova2021.m5.011 


\section{INTRODUCCIÓN ${ }^{1}$}

En lo que sigue no hay demasiado suspense. Quiero decir que la conclusión — palabra siempre demasiado taxativa, intimidante—, si la hay, está ya dada desde el principio y debería tomarse entonces como hipótesis: no tengo claro qué queremos decir con «ironía» o «irónico», creo que hay un genuino problema de traducción en torno a ese término, una dificultad mayúscula con la codificación de esa experiencia. $\mathrm{Y}$, al mismo tiempo, considero que la ironía y lo irónico son rasgos centrales de nuestro tiempo y que si atendemos a la metamorfosis que han experimentado en diferentes momentos y contextos culturales tal vez podamos aprender algo más acerca del que nos ha tocado vivir.

La ironía puede entenderse como una figura retórica, como un estilo o un tono que apunta hacia una inconsistencia, hacia una tensión entre lo que se dice y la intención con que se dice. Habría, por tanto, una incongruencia entre expresión y significado. Ello la aproximaría a la paradoja y a la sátira. Hay en la ironía un coqueteo con la contradicción y una discrepancia en la información: alguien no sabe todo lo que dice, no dice todo lo que sabe o, al menos, al lector o al espectador le queda esa impresión, la de que hay algo en otra parte que explica esa oscilación que percibe, una clave que disolvería esa ambigüedad. Pero no está claro que la ironía sea hoy únicamente una herramienta, un tropo al servicio de un objetivo distinto de ella misma.

Desde un punto de vista retórico, la ironía puede interpretarse como un recurso dramático o literario presente en la tragedia y en el campo novelesco o como algo que va más allá de un determinado personaje o género y afecta a la totalidad de la trama o de la historia. Dentro de este ámbito, el tipo de ironía más interesante para mi propósito es el de la «ironía cósmica», pues parece implicar una actitud general hacia la totalidad de lo real y la limitada capacidad de diagnóstico e intervención humana en el curso de las cosas.

\footnotetext{
${ }^{1}$ Este artículo tuvo su origen en una intervención en el «Seminario Ironía y transformación social. La reflexión estética de Friedrich Schlegel y la historia cultural de la exclusión», celebrado los días 20 y 21 de abril de 2021 en el Círculo de Bellas Artes, organizado por Ana Carrasco-Conde, Germán Garrido y Nuria Sánchez Madrid (Grupos de Investigación UCM GINEDIS e Historia y Ontología del Presente) - Proyecto Santander-UCM PR87/19-22633 a quienes estoy muy agradecido por haber considerado que tenía algo que decir.
} 
No obstante, no me ocuparé tanto de la ironía desde un punto de vista técnicotropológico intentando cubrir exhaustivamente sus posibilidades en el orden del discurso ${ }^{2}$, sino que atenderé a cómo ha variado su función: de herramienta al servicio de un proyecto de transformación social a cosmovisión que se agota en sí misma. En efecto, tal como veo las cosas, habría tenido lugar una transición que va desde la ironía socrático-platónica vinculada a una reforma —o a una revolución, si se quiere- pedagógico-política (en el sentido de la paideia griega), pasa por el momento romántico — que conserva la idea de distancia y resistencia frente al orden establecido- y desemboca en el ámbito contemporáneo-postmoderno en el que la ironía se encuentra próxima al sarcasmo sin objeto y al cinismo, o, dicho de otra manera, es absolutamente compatible con el conformismo social o el fatalismo.

Para esta travesía que propongo al lector no hay mejor guía que una cita de Kierkegaard en su conocido tratado sobre la ironía que altero ligeramente: «La ironía es una vampira que chupa la sangre de su amante, le abanica con su frescor, le arrulla hasta dormirle y le atormenta con sueños turbulentos» ${ }^{3}$; se trata de una fórmula que advierte del carácter tentador y parasitario de este recurso y anticipa que en nuestro particular viaje a través del tiempo asistiremos al espectáculo de la corrupción —o la distorsión— de lo que quizá alguna vez fue una virtud.

Lo que planteo a continuación no será necesariamente una historia lineal, sino que también podría verse como un esquema de lectura por díadas que se vinculan a través de los siglos; por ejemplo, cabría establecer una correspondencia entre la ironía socrático-platónica y la propuesta contemporánea de Rorty por una parte, y entre el modelo romántico y las consideraciones de Foster Wallace por otra. La torsión que a mi juicio experimenta la ironía en ese tránsito nos devuelve al interrogante inicial, el de si el cambio de sensibilidad al que apunta permite que sigamos empleando el mismo término para esos distintos momentos.

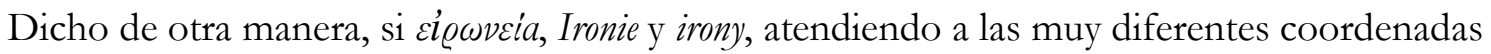
ontológicas de las que parten, podemos traducirlos con la misma palabra.

\footnotetext{
2 Véase la rigurosa monografía de Ballart (1994) y, con otro enfoque, los sucesivos trabajos de Raga Rosaleny $(2007,2007 b, 2007 c, 2008)$. Una vez terminada la redacción de este texto tuve noticia de la obra de Santiago Gerchunoff, Ironía On (Gerchunoff, 2019), con el que comparto muchos referentes, aunque tanto su punto de partida como las conclusiones a las que llega difieren de los míos. En cualquier caso, se trata de una lectura tan recomendable como sugerente, amena e informada y agradezco a Nerea Blanco Marañón el haberme señalado su pertinencia.

3 Tomado de Hutcheon, 1994: ix.
} 


\section{EL MOMENTO CLÁSICO}

Si pensamos en Sócrates, la ironía se identifica con un ejercicio de modestia por parte del orador que, a través de la presunta ventaja retórica que ello le confiere, busca incitar al cuestionamiento de los valores y conocimientos tradicionales; la ironía está, por tanto, al servicio de un proyecto de desestabilización que persigue una transformación radical del ser humano a distintos niveles (epistemológico, social, político, y moral).

La ironía socrática implica una toma de distancia respecto al pensamiento ordinario acerca de lo importante, que huye de las respuestas concluyentes y de las posiciones rígidas. Se puede interpretar como un gesto de cautela o de humildad consistente en devolver la pregunta al interlocutor para construir juntos una respuesta, algo que, no obstante, puede llegar a resultar irritante. A este respecto uno de los pasajes más célebres está en República I 337a y ss. cuando, en una discusión acerca de nada menos que «lo justo», Trasímaco recrimina a Sócrates su habitual maniobra elusiva:

Tras escucharme, Trasímaco se echó a reír con grandes muecas, y dijo: -¡Por Hércules! Esta no es sino la habitual ironía de Sócrates, y yo ya predije a los presentes que no estarías dispuesto a responder, y que, si alguien te preguntaba algo, harías como que no sabes, o cualquier otra cosa, antes que responder.

Es interesante lo que apunta el traductor, Conrado Eggers Lan, acerca de esa risa y de esas muecas previas: el adjetivo que hay debajo es sardánion, que es de donde procede nuestro «sardónico» y podríamos anticipar ya aquí una reverberación de la ironía socrática en la risa sardónica que acompañaría a cierto humor postmoderno (de Kafka a David Foster Wallace). En cualquier caso, lo que parece más o menos claro es que en la ironía socrática no vamos a encontrar una indiscriminada función disolvente que ponga en cuestión las bases mismas de lo real, que es una de las características que tendrá en momentos posteriores. $\mathrm{O}$, mejor dicho, sí tiene esa pretensión de alcance, pero ello queda supeditado a un momento fundante posterior. En efecto, aunque el proyecto de Sócrates pasase por una desestabilización universal, como se concluye de ciertos pasajes de Kierkegaard, «Cuanto más desestabilizaba Sócrates la existencia, tanto más profunda y necesariamente debía gravitar cada una de sus expresiones particulares hacia la totalidad irónica que, como estado espiritual, era infinitamente insondable, invisible, indivisible» (2000: 89), Sócrates disponía —y 
proporcionaba - una alternativa completa a esa cosmología que quería reformar: el momento disolvente era una estación de paso, no un destino final («Como lo negativo, la ironía es el camino; no la verdad, sino el camino», Kierkegaard, 2000: 340).

Incluso desde un registro más restringido como puede ser el de la retórica, también la ironía aparece asociada a la virtud y a la elegancia. Para Aristóteles es un recurso que caracteriza al hombre libre en el empleo del humor en los debates, «La ironía es más propia del hombre libre que la burla, pues la primera se aplica sobre uno mismo y la burla sobre los demás» (Rh. 1419b7). En este contexto, además de ser un instrumento defensivo ante un auditorio poco propicio puede ser interpretado como signo de modestia y de conciencia del límite.

Pero, aunque se rebase el estricto ámbito de la retórica y atendamos a su dimensión ético-existencial, hemos de decir que en este «momento clásico» la ironía está bajo control y supone una herramienta de conocimiento y relativización del mundo que permite aprender, intervenir y posibilita vivir de un modo más pleno. Esta plenitud —o autenticidad— tendría que ver con la altura filosófica o poética de la propia vida, al menos para alguien como Kierkegaard para quien, como buen romántico, la biografía es esencial: considera que la ironía nació con Sócrates, que hubo entonces un ironista antes que el concepto en abstracto, y que el modo en que Sócrates armonizó su vida — ¿y su muerte? — a su visión y a su proyecto resulta indispensable para entender este particular phármakon (2000: 338 y ss.). La ironía (socrática) sería lo que permitiría llevar a cabo una existencia trágica, es decir, ser consciente del carácter absurdo del mundo y de la vida y no dejarse arrastrar por el desánimo o la desesperación, empeñarse en crear y creer, un proyecto vital que late bajo las propuestas del mismo Kierkegaard y llega hasta Nietzsche o Camus.

\section{EL MOMENTO ROMÁNTICO}

La sensibilidad romántica que emblematiza Friedrich Schlegel es ya una sensibilidad histórica, esto significa que resulta inseparable de la experiencia lineal e irreversible del tiempo desde un punto de vista colectivo y que, además, se asienta en una conciencia de crisis y distancia respecto al presente - los vínculos entre el Romanticismo y la modernidad/contemporaneidad son innumerables-. En este contexto, la ironía es contemplada como una virtud ligada a la reflexión, a la creación artística y a la propia actitud 
vital. Como acabamos de ver, el ejemplo es Sócrates, que parece condensar ese gran título de Pierre Hadot, La filosofía como forma de vida, una forma de vida (romántica y romantizada) para la cual la ironía se presenta como indispensable.

Prestaré atención a algunos fragmentos de Schlegel especialmente significativos para que nos intentemos hacer cargo de lo que hay en juego en el caso de conceder que este autor sea la expresión más lúcida de la ironía romántica (no son pocos los analistas y comentaristas que manifiestan esta postura, quizá uno de los más célebres Paul de $\mathrm{Man}^{4}$ ).

El primero de ellos alude a la intimidad que según él se da entre ironía y filosofía: «La filosofía es la auténtica patria de la ironía, que podría definirse como belleza lógica» (Schlegel, 2009: 34). La ironía se presenta como una virtud asociada al desasimiento, a la distancia y a la elevación capaz de contemplar las cosas de un modo más profundo/esencial/completo (algo que, en la sensibilidad romántica, precursora del actual gusto por lo gótico-siniestro, incluye el $\operatorname{caos}^{5}$ ). A pesar de que la ironía aparece vinculada aquí a los géneros (tanto a la filosofía como a la poesía, de la que se dice que puede alcanzar tan altas cotas como aquélla, una posición absolutamente representativa de Schlegel ${ }^{6}$ ), tengo la sensación de que, como sucedía en Kierkegaard, en realidad parece que se esté pensando más en un rasgo de personalidad, en un determinado carácter o modo de ser. Así se concluye de las palabras que, dentro del mismo fragmento, dedica Schlegel al «divino hálito» de la ironía presente en poemas de toda época:

Habita en ellos una bufonería auténticamente trascendental: en el interior, aquel estado de ánimo que lo abarca todo con la mirada y que se eleva infinitamente por encima de todo lo condicionado, incluso por encima del propio arte, la propia virtud o la propia genialidad; y en el exterior, aquella ejecución que presenta el estilo mímico de cualquier buen bufón italiano corriente. (Schlegel, 2009: 35)

Veo aquí algo que va más allá de la apreciación estética y entra casi en el terreno de la propedéutica vital, un elogio del contraste entre la profundidad de la mirada y la liviandad del gesto que entronca con el programa narrativo que siglos después enunciara Kundera y en el que cabría inscribir a ilustres representantes de la postmodernidad literaria, caso de Italo Calvino o el mismo David Foster Wallace:

\footnotetext{
${ }^{4}$ Para los propósitos de este texto véase De Man, 1996; agradezco a Ramón del Buey el haberme insistido en la importancia de esta referencia.

5 «La ironía es la clara consciencia de la eterna agilidad, de la infinita plenitud del caos» (Schlegel, 2009: 204).

6 Véase Garrido Miñambres, 2021.
} 
Unir la extrema gravedad de la pregunta a la extrema levedad de la forma es desde siempre mi ambición. Y no se trata exclusivamente de una ambición artística. La unión de un estilo frívolo y un tema grave desvela la terrible insignificancia de nuestros dramas (tanto los que ocurren en nuestras camas como los que representamos en el gran escenario de la Historia). (Kundera, 2012: 118).

La ironía así entendida es una cuestión que atañe al estilo en su noción más profunda, aquella que lo considera casi una proyección del autor, de su mirada y de la metafísica que lo asiste y de la que participa. No es extraño entonces que busquemos también las implicaciones ontológicas que tiene tan alta consideración de la ironía. A este respecto destacan en primer lugar la tensión y la ambivalencia, que aparecen como rasgos irrenunciables en toda apuesta mimética que se pretenda elevada y rigurosa: «La ironía constituye la forma de lo paradójico. Paradójico es todo aquello que es bueno y grande a la vez» (Schlegel, 2009: 36). Se trata de una paradoja dialéctica que se proyecta tanto hacia la realidad efectiva externa como hacia el carácter de aquél que la ejerce, y que funciona también como divisa para los espíritus más nobles:

Es la más libre de las licencias, pues permite que uno se traslade y se eleve por encima de sí mismo y, aun así, es la más legítima, porque es absolutamente necesaria. Es una buena señal que las personas armónicamente banales no sepan cómo tomarse esta constante autoparodia, que vayan constantemente de la creencia a la desconfianza hasta marearse y acaben tomando en serio lo que es broma y en broma lo que es en serio (Schlegel, 2009: 49).

No se le escapará aquí al lector el peligro de autodestrucción que tan particular juego entraña - la ironía es una vampira...-, también en lo que respecta al mundo, cuya idea de perfección está ligada a la contradicción y a lo conflictivo: «Una idea es un concepto perfecto y acabado hasta la ironía, una síntesis absoluta de antítesis absolutas, la alternancia que se genera a sí misma constantemente de dos pensamientos en conflicto» (Schlegel, 2009: 84). La proximidad —y quizá la dependencia — de lo planteado por Schlegel a propósito de la ironía con la dialéctica filosófica de origen fichteano es algo en lo que insiste Paul De Man en el mencionado texto El concepto de ironía. Estoy de acuerdo con él en que la ironía estudiada desde estas coordenadas rebasa el campo de lo retórico y lo poetológico, pues la estructura misma de lo efectivamente real es lingüística, incluso desde su misma fundación: 
[A propósito de Fichte] La estructura del sistema es tropológica. Es el sistema tropológico en su forma más sistemática y general.

Pero no solamente es eso, es también un sistema performativo, hasta el punto de que se asienta sobre el acto original de postular que existe en el modo lingüístico bajo la forma de la catacresis, del poder de setžen, que es el inicio del sistema y que es él mismo algo más performativo que cognitivo. En primer lugar, hay un performativo, el acto de postular, la catacresis original, que después se mueve hacia un sistema de tropos (De Man, 1996: 14)

La ironía plantea una duda, una oscilación, en el seno del sistema mismo, una desestabilización de alcance metafísico que afecta a la credibilidad del todo. Las observaciones de De Man poseen un alcance ontológico que el autor belga no acaba de ver (o no termina de atreverse a plantear con rotundidad) ${ }^{7}$ :

si Schlegel dijo que la ironía es una permanente parábasis, nosotros diríamos que la ironía es la permanente parábasis de la alegoría de los tropos [...] La alegoría de los tropos tiene su propia coherencia narrativa, su propia sistematicidad, y es tal coherencia, tal sistematicidad, lo que la ironía interrumpe, altera. De este modo, se podría decir que cualquier teoría de la ironía es la ruptura, la necesaria ruptura, de cualquier teoría narrativa, y resulta irónico, como se suele decir, que la ironía aparezca siempre en relación con las teorías de la narrativa, cuando la ironía es precisamente la que constantemente hace imposible alcanzar una teoría de la narrativa que sea consistente. Ello no quiere decir que no debamos ser conscientes de que siempre resultará interrumpida, alterada, rota por la dimensión irónica que necesariamente contendrá (De Man, 1996: 18)

Si lo efectivamente real está compuesto de una red tropológica a partir de ese primer momento tético, fundante, la ironía constituye no sólo una amenaza narrativa sino cósmica, ontológica; lo que arruina no es lo dialéctico y lo reflexivo sino el encantamiento, la condición misma que presupone la función simbólica y discursiva, la ilusión de correspondencia o de referencia nítida. La ironía es, si acaso, el exceso de reflexión (y de dialéctica) que coincide con la voz pesadillesca del demonio que atormentaba a Descartes, que aparece aquí reencarnado en una figura burlesca cuya risa nos acompañará en la siguiente estación de nuestro viaje: «Lo bufo, aquello a lo que Schlegel se refiere al hablar de la commedia dell'arte, es la interrupción de la ilusión narrativa, el aparté, el aparte para la audiencia, a través del que se rompe la ilusión de la ficción» (De Man, 1996: 16).

\footnotetext{
${ }^{7}$ A lo largo de unas páginas brillantes, De Man reconduce la posición de Schlegel a la relación tropológica que se deduce de la dialéctica de Fichte y reivindica el carácter fundante — postulante — que desempeña el lenguaje en su sistema, así como las implicaciones que esto tiene para la propia función metafórica, pero no termina de culminar ese trayecto que, a mi juicio, en una retrospectiva verdaderamente radical le debería haber llevado a examinar el inquietante papel ontológico-lingüístico-epistemológico que desempeña la analogía en Aristóteles (véase De Man, 1996: 10-14).
} 
La ironía sin bridas supone la parábasis que todo lo pone en suspenso, la llamada de atención y la duda acerca del suelo que pisamos, ¿cómo no ver en esa quiebra de la ilusión un parentesco con la muerte de Dios, un antecedente del desfondamiento de los grandes relatos que articulaban nuestra experiencia colectiva de los que hablaba Lyotard?

\section{EL MOMENTO POSTMODERNO}

Muchas son las cosas que separan nuestros días de los habitados por Sócrates o Schlegel, pero una de las características que más contribuyen a esa distancia es la ilegibilidad del mundo, la sensación que tenemos de afrontar una crisis de representación; como bien apuntó Fredric Jameson, somos incapaces de plantear un modelo, una cartografía, que resuma el sistema y contribuya a orientarnos en el flujo de poder y de información en el que nos encontramos inmersos. Las repercusiones de ese bloqueo de la imaginación se dejan sentir en diversos ámbitos; desde el punto de vista artístico, reflexivo y literario cabe constatar la renuncia al sueño romántico de lograr la Gesamtkunstwerk —la obra de arte total—, el desfondamiento de la forma «sistema» tras el mismo Hegel y la falta de confianza en la capacidad mimética del arte. Llegados a este punto, el «realismo» se nos presenta no tanto como una etiqueta insuficiente sino como un verdadero arcaísmo.

En nuestra época, la ironía, más que un recurso puntual o una herramienta al servicio de la transformación social o de un proyecto vital que aspira a una mayor plenitud, parece ser un automatismo que refleja el carácter cada vez más elusivo de la presunta realidad efectiva.

Por lo demás, no es necesario darle muchas vueltas al asunto para comprender que la ironía es una modalidad del pensamiento y del arte que emerge sobre todo en épocas de desazón espiritual, en las que dar explicación a la realidad se convierte en un propósito abocado al fracaso. La orfandad existencial y moral en que Occidente se encuentra desde la caída del Antiguo Régimen explica que la ironía se haya convertido en uno de los distintivos de la modernidad, si por este incómodo y voluble concepto entendemos la tradición de imaginación y pensamiento que inauguró el Romanticismo, y que la entrada en nuestro siglo no hizo sino agudizar. Desde una perspectiva intelectual, si algo caracteriza nuestro tiempo es la pérdida del sentido unívoco de lo real: la complejidad de nuestro mundo, las contradicciones, a menudo cruentas, entre las palabras y los hechos, abonan el que la literatura, por su excepcional capacidad mimética respecto a las demás artes, se haya hecho eco como ninguna otra de la 
alienación, la distorsión, el absurdo que acechan a diario al conjunto de los hombres. (Ballart, 1994: 23-24)

Desde el campo literario algunas de las mejores reflexiones dedicadas a la ironía se las debemos a David Foster Wallace, que encontró en esta figura su némesis o su sinestro cómplice. Se refiere a ella de un modo u otro a lo largo de toda su trayectoria, pero tiene un protagonismo especial en su conocido ensayo acerca de la influencia de la televisión en la narrativa norteamericana E Unibus Pluram, de 1993. Allí muestra las paradójicas bases sobre las que se asienta la realidad contemporánea, el irónico resultado en el que culminó el proyecto cosmopolita de la Ilustración:

La apoteosis del pop en el arte de la postguerra determinó un nuevo matrimonio entre la cultura de elite y la cultura popular. Porque la viabilidad artística del posmodernismo fue consecuencia directa, nuevamente, no de ninguna novedad en el terreno del arte, sino de la nueva importancia de la cultura comercial de masas. Los americanos ya no parecían unidos tanto por creencias comunes como por imágenes comunes: lo que nos une se ha convertido en aquello de lo que somos testigos. Nadie ve esto como un cambio positivo. De hecho, las referencias a la cultura pop se han convertido en metáforas tan potentes en la narrativa norteamericana, no solamente por lo muy unidos que estamos los americanos en nuestra exposición a las imágenes de masas, sino por nuestra psicología culpable e indulgente respecto a esa exposición. Dicho de forma simple, las referencias pop funcionan tan bien en la narrativa contemporánea porque a) todos reconocemos esas referencias, y b) todos nos sentimos un poco incómodos por reconocer esas referencias. (Foster Wallace, 2008: 57-58)

Para Foster Wallace la ironía es el rasgo principal del discurso televisivo contemporáneo y pasa por el conocimiento de sus propios límites, por la exposición de sus mecanismos de manipulación y de su carácter superficial y por tomarse a sí mismo como referencia; una espiral discursiva que, por ser las pantallas la principal fuerza que configura la realidad, podríamos decir que pertenece a la realidad misma. La ironía aparece entonces próxima a la razón cínica analizada por autores como Peter Sloterdijk o Slavoj Žižek, un rasgo ideológico que constituye una variante del conocido lema marxista «no lo saben, pero lo están haciendo» y que desemboca en el siniestro «saben perfectamente lo que están haciendo y lo hacen de todos modos». En un prodigioso giro de guion, la otrora peligrosa ironía, un procedimiento que, liberado sin control, podría tener una recursividad infinita y que amenazaba con disolverlo todo ${ }^{8}$, se convierte en la postmodernidad en una fuerza

8 Véase Booth, 1974: p. 59, nota 14; tomado de De Man, 1996: 3. 
conservadora, garante de la realidad misma. Una realidad cada vez más indistinguible de la ficción y que parece tejida con los recursos narrativos con los que Fredric Jameson caracterizó los productos culturales propios del postmodernismo: el pastiche, el collage, lo kitsch. Hay cierta coherencia entonces en esa traslación de la ironía que la lleva del ámbito lingüístico al ético y al metafísico: de recurso retórico prestigioso en la antigüedad clásica, rasgo de personalidad en Sócrates y en los románticos, a atributo cosmológico en la postmodernidad. Nótese que ello no significa que la ironía haya dejado de ser una valiosa herramienta retórica ni que no tenga que ver con determinados caracteres — de hecho, como decíamos más arriba, esto último se ha exacerbado y podríamos decir que la ironía se ha convertido en el rasgo típico de la sensibilidad contemporánea-, pero todo ello se encuentra supeditado a esa dimensión sistémica. La ironía ya no es ninguna prerrogativa de una elite o de una vanguardia artística o filosófica, sino el mecanismo habitual con el que se articula el discurso de los medios de comunicación de masas y el subterfugio mediante el que los supuestamente lúcidos y críticos acatan el mismo programa que todos los demás ${ }^{9}$, una especie de — solidísimo_ - doble vínculo que apuntala nuestra realidad social. La ironía postmoderna funciona como salvoconducto que exime de culpa al consumidor de algo que se sabe superficial, grosero o de algún modo intolerable, es el mecanismo mediante el cual se establece una complicidad de clase entre el emisor y el receptor que sitúa a ambos por encima del contenido aparente (y degradado). A veces ni siquiera es preciso que esa ironía se muestre por parte del difusor del contenido, pudiendo ser únicamente una disposición —o mejor, una pose- que adopta el lector-espectador a la hora de procesarlo, un recurso que apela a su presunta superioridad intelectual respecto a quien se lo toma de un modo más directo o literal.

El propio David Foster Wallace parece enredado de un modo letal en la tela de araña que plantea la ironía: a pesar de usarla con profusión en sus relatos y en sus crónicas, de explorar hasta la saturación los múltiples juegos de referencias, meta-referencias, listas, sobreentendidos y notas a pie de página, parece añorar un tipo de literatura -y de experiencia- más sincera, elemental y narrativamente pura.

Me parece que la intelectualización y estetización de los principios y valores en este país es una de las cosas que ha destrozado a nuestra generación. Todo aquello que mis padres me decían, como «Es muy importante no mentir». Vale, controlado, lo tengo. Asiento pero en realidad no lo siento. Hasta que llego

\footnotetext{
9 Véase Foster Wallace, 2001: 42-43.
} 
a los treinta y me doy cuenta de que, si te miento, yo tampoco puedo confiar en ti. Me siento dolido, estoy nervioso, estoy solo, y no puedo descubrir por qué. Y entonces me doy cuenta, «Ah, quizá el modo de abordarlo sea de verdad no mentins. La idea de que algo tan simple y, en realidad, tan estéticamente poco interesante - lo que para mí significaba que había que olvidarse de las cosas interesantes y complejas - pueda ser verdaderamente sustancioso de un modo en que lo pícaro, lo meta, lo irónico y lo posmo no pueden me parece importante. Me parece que es algo que nuestra generación necesita experimentar. (Foster Wallace en Burn, 2012: 88)

La ironía parece indicar que se participa del fraude ${ }^{10}$ — del carácter fraudulento de la realidad toda- pero que se es consciente de ello, que se hace sin convicción, como por una extraña inercia, intentando que esa forma de conciencia tenga un carácter exculpatorio, que atenúe la complicidad del que la ejerce. En tal caso, la víctima de la ironía no sería el orden establecido, sino aquel que participa de ella y le sirve como huésped.

Hablábamos más arriba del humor asociado a la ironía; pues bien, en este punto hemos de decir que la risa que acompaña a la ironía postmoderna es una risa perturbadora, que no evidencia tanto un signo de ingenio, como en el contexto retórico al que se refería Aristóteles, sino una forma de impotencia, una especie de risa floja que aúna el reconocimiento de una situación y el absurdo o ridículo papel que le resta al ser humano involucrado en ella. Se trata de un humor característicamente kafkiano, que hace que se desdibujen las fronteras entre lo irónico, lo sarcástico y lo sardónico y que da la medida de nuestra insignificancia de un modo insólito, radicalmente distinto a como sucedía en otros momentos de la historia.

En el mundo de lo kafkiano, lo cómico no representa un contrapunto de lo trágico (lo tragicómico) como ocurre en Shakespeare; no está ahí para hacer lo trágico más soportable gracias a la ligereza del tono; no acompaña a lo trágico, no, lo destruye antes de que nazca, privando así a las víctimas del único consuelo que les cabría aún esperar: el que se encuentra en la grandeza (auténtica o supuesta) de la tragedia (Kundera, 2012: 127).

Nuestro mundo se caracteriza por la desactivación de todo ámbito trascendente que ejerza una acción tutelar o normativa sobre el presente, de ahí que la propia idea —y quizá la sensación misma- de grandeza se encuentre bajo sospecha ${ }^{11}$. El que nuestro vocabulario

\footnotetext{
10 Sobre David Foster Wallace y el fraude véase Sánchez Usanos, 2020.

${ }^{11}$ Esto es algo que está en la base de la sensibilidad camp, tan contemporánea y tan próxima a esa actitud, disposición o forma de recepción irónica de la que estamos hablando y que tan bien cartografió en su momento Susan Sontag.
} 
y nuestra experiencia están configurados atendiendo o presuponiendo la trascendencia y no tanto la inmanencia es un asunto que preocupa a la filosofía desde Kant hasta Nietzsche, y el que la ironía postmoderna tienda a disolver esa posibilidad la convierte en un rasgo crepuscular, tardío: un síntoma de agotamiento acompañado de una risa y de un humor kafkiano ${ }^{12}$ y terminal.

No es extraño entonces el que Northrop Frye en su Anatomía de la crítica hablase de la ironía en el apartado correspondiente a los «mitos de invierno»

Llegamos ahora a los patrones míticos de la experiencia, a los intentos de dar forma a las ambigüedades y complejidades veleidosas de la existencia no idealizada. No podemos descubrir estos patrones meramente en el aspecto de representación, o mimético, de esta literatura, ya que ese aspecto es el del contenido y no el de la forma. En cuanto estructura, el principio central del mito irónico se deja abordar mejor como parodia del romance: la aplicación de las formas míticas románticas a un contenido más realista que se ajusta a ellas de un modo insospechado. [...]

La diferencia principal entre la ironía y la sátira es que la sátira es una ironía militante: sus normas morales son relativamente claras y asume criterios con los cuales se miden lo grotesco y lo absurdo. La pura invectiva o el insulto es una sátira en la que hay relativamente poca ironía: por otro lado, cada vez que un lector no está seguro de cuál es la actitud del autor o de cuál se supone que sea la suya, hay ironía con relativamente poca sátira (Frye, 1991: 293-294).

La sátira exige un posicionamiento moral por parte del que la ejerce y eso implica cierta capacidad de representación y cierto programa de transformación que hemos visto que se ha ido diluyendo. La ironía nos transmite entonces una sensación de oscilación difusa que se corresponde más con nuestra posición frente al sistema que con su falta de solidez - el triángulo formado por la postmodernidad, la globalización y el modo de producción capitalista parece bastante estable- La ironía parece entonces el tono emocional y psicológico que propicia una realidad efectiva próxima al simulacro, la noción que explotó con lucidez Baudrillard para caracterizar nuestro presente. Por eso llama la atención —por su carácter anacrónico, inesperado y casi trágico - el que la figura del ironista sea recuperada por parte de uno de los filósofos más reiteradamente acusados de postmoderno, Richard Rorty, y que lo haga no para pasear la mirada sobre las ruinas del presente como un flâneur despreocupado y con un punto morboso, sino justamente para instaurar una suerte de pacto social-epistemológico de madurez (a su manera Rorty es un heredero del pensamiento ilustrado).

12 Sobre Kafka y lo cómico véase el excelente texto de Foster Wallace, «Algunos comentarios sobre lo gracioso que es Kafka, de los cuales probablemente no he quitado bastante» (Foster Wallace, 2014: 79-84). 
Hay títulos que tienen la virtud de condensar toda la propuesta filosófica de su autor -lo cual, claro está, no sustituye a su presentación ni a su desarrollo-_, es el caso, por ejemplo, de El mundo como voluntad y representación de Schopenhauer y también el de Contingencia, ironía y solidaridad de Richard Rorty. Lo que nos plantea el filósofo estadounidense pasa por hacernos cargo de lo que la propia historia del pensamiento filosófico y científico nos enseña si sabemos interpretarla: que no hay un ámbito privilegiado de acceso a lo objetivo, a lo verdadero, que no hay una instancia superior a nosotros mismos que nos permita juzgar, organizar ni dar respuesta a las preguntas kantianas — ¿qué puedo saber?, ¿qué debo hacer?, ¿qué me cabe esperar? - , que somos seres sociales e históricos y que, en buena medida, construimos nuestros propios problemas y nos constituimos a nosotros mismos en la búsqueda de soluciones, que el peso de esa responsabilidad y esa soledad es difícil de soportar y solemos buscar refugios trascendentes o sobrehumanos, que, en suma, resulta difícil hacerse cargo. La ironía significa en Rorty precisamente la toma de conciencia de nuestra contingencia constitutiva, de la responsabilidad colectiva que nos asiste a la hora de dar respuesta a lo que sí debemos hacer: aumentar la libertad y disminuir el dolor socialmente condicionado. La ironía equivale, en un nuevo giro de guión, a una especie de lucidez trágica que asume la soledad radical del ser humano después de la muerte de Dios pero que no la traduce en ningún ejercicio de fuga estético-existencial en clave individual, sino en una tarea comunitaria infinita consistente en ponerse de acuerdo con los demás sabiendo que no hay nada a lo que apelar fuera del propio contexto retórico de decisión.

Con Rorty la ironía recupera la dimensión cívica que acaso tuvo con Sócrates, pero sin la asistencia ni la garantía de un programa metafísico ni de un orden cosmológico-moral al que subordinar la propuesta política. Si la ironía y lo irónico, sobre todo en su uso corriente en el ámbito angloamericano, equivale casi a la paradoja y lo paradójico, a la tensión que emana de una situación o circunstancia en la que se dan dos rasgos o características divergentes, opuestas o incluso contradictorias, en Rorty se da la meta-ironía, pues su propuesta irónica aúna la ambición — ¿épica?, ¿trágica? - de una sociedad capaz de vivir y de razonar sin dioses ni sucedáneos de dioses — próxima a los Übermenschen nietzscheanos, entonces-, de asumir la contingencia y la finitud radicales, con un compromiso por opciones concretas tan poco románticas como la democracia liberal o las reformas legislativas; esa unión de lo utópico con lo administrativo-burocrático bien puede ser calificada de irónica en el sentido que antes apuntábamos, como también lo fue su propia figura: en lo profesional menospreciado por la filosofía académica y apenas tolerado por los 
departamentos de estudios literarios, y en lo intelectual-político situado siempre bajo la incomprensión y el fuego amigo:

La palabra preferida por la izquierda para criticarme es «autocomplaciente», mientras que la derecha habla con la misma predilección de «irresponsabilidad».

La hostilidad de la izquierda se puede explicar en parte por el hecho de que la mayoría de las personas que admiran tanto como yo a Nietzsche, Heidegger y Derrida —o sea, la mayoría de las personas que se identifican a sí mismas con la «postmodernidad» o que son clasificados (como yo) nolens volens como posmodernos- participan de la «lucha competitiva por insultar a Estados Unidos», por adoptar una expresión de Jonathan Yardley. Los participantes en esta competición se esfuerzan por encontrar calificativos cada vez mejores y más duros para Estados Unidos. Ven en nuestro país la encarnación de todo lo que se puede criticar en el rico Occidente de la época post-ilustrada. Según su concepción, vivimos en una «sociedad disciplinaria», como lo llamó Foucault, es decir en una sociedad que está dominada por el repugnante ethos del «individualismo liberal», que a su vez genera el racismo, el sexismo, el consumismo y a los presidentes republicanos. Yo, en cambio, veo Norteamérica de manera muy parecida a Whitman y Dewey y pienso que ofrece perspectivas democráticas ilimitadas. En mi opinión — pese a sus antiguos y actuales horrores y vicios y su disposición permanente a elegir necios y bribones para que ocupen los altos cargos-, nuestro país es un ejemplo del mejor tipo de todas las sociedades que se han ideado hasta ahora. Desde la óptica de la izquierda, esta concepción es el colmo de lo políticamente correcto.

La hostilidad de la derecha se explica en gran medida por el hecho de que los autores derechistas consideran una simple preferencia por las sociedades democráticas como insuficiente. Según ellos, habría que creer además que son objetivamente buenas y que las instituciones de tales sociedades se basan en principios supremos de razón. Sobre todo cuando se enseña filosofía — como yo-, esperan de uno que transmita a la juventud que su sociedad no sólo se cuenta entre los mejores proyectos hasta ahora habidos, sino que es una sociedad que encarna la verdad y la razón. Si uno se niega a decir tales cosas, esto se interpreta como «abuso del cargo»: como recusación de la responsabilidad profesional y moral. Mis propias concepciones filosóficas - que son las concepciones que comparto con Nietzsche y Dewey - me prohíben hacer semejantes afirmaciones. Conceptos como «valor objetivo» $\mathrm{y}$ «verdad objetiva» no me sirven de mucho (Rorty, 2008: 136-137)

En este momento postmoderno se entrelazan los dos momentos anteriores, la ironía individual, lúcida y desencantada del romanticismo encuentra en David Foster Wallace su heredero natural, apuntalado, además, por su suicidio, una muerte anticipada en cierto modo por textos como El neón de siempre o Esto es agua, un suicidio «romántico» que parece el anverso de la cicuta socrática: allí donde el filósofo griego asume de forma irónico-trágica su injusta condena para salvaguardar el orden de la pólis y la coherencia de su propuesta 
filosófica, el escritor norteamericano parece expresar una impotencia estético-existencial para adaptarse a un mundo que conoce a la perfección y que, en cierto modo, desprecia.

Mientras tanto, el modelo metafísico-epistemológico acorde con los tiempos es presentado y defendido por Richard Rorty que, como un Sócrates trasmutado, lo pone al servicio no tanto de un nuevo orden social, sino de una nueva manera de relacionarnos y asumir el orden social efectivamente existente, un intento retórico de encontrar la legitimidad de un sistema precisamente donde otros ven una amenaza, resituando la ironía como una herramienta al servicio de la convivencia, tal y como funcionaba en el programa socrático. Pero lo hace —y esto también puede que sea «irónico»— sin recurrir como aquél ni a un repertorio mitológico ni a un final melodramático.

Veo, no obstante, un tanto forzado el empeño de Rorty en usar «ironía» e «ironista» para calificar su posición, casi como si fuese un anacronismo o un intento de homenajear a Sócrates y a su legado, lo cual nos empuja a buscar la analogía con otra de las grandes figuras irónicas de la historia de nuestra cultura, el apasionado lector, antagonista de la realidad e ingenioso hidalgo don Quijote de la Mancha.

Y tal vez todo esto evidencia que la ironía y los problemas de traducción que emblematiza no son sino el reflejo de nuestra propia posición en el mundo, que tal vez la relación que mejor defina la del ser humano y la vida sea la de «falsos amigos», esa trampa que plantea la semántica, la grafía y la eufonía para hacer creer al traductor que una palabra o una expresión que se pronuncia o se escribe de forma similar en dos idiomas distintos significa lo mismo; nosotros y la vida: dos ámbitos de la realidad que parecen converger y que de hecho lo hacen hasta que llega el daimon y liquida la ilusión.

$\mathrm{Y}$, sin embargo, no nos queda más remedio que seguir jugando, presuponiendo un orden, una continuidad y un sentido, atribuyéndonos una capacidad de acción que sabemos que probablemente pertenezcan más al ámbito de la narrativa que al de la realidad efectiva, un juego que se sabe tal, pero al que no queremos ni debemos renunciar. Es (lo) irónico. 


\section{BIBLIOGRAFÍA}

Aristóteles (1926): Art of Rhetoric, traducción al inglés de J. H. Freese, Loeb Classical Library 193, Cambridge, Massachusetts, Harvard University Press.

Ballart, Pere (1994): Eironeia. La figuración irónica en el discurso literario moderno, Barcelona, Quaderns Crema.

Booth, Wayne C. (1974): A Rhetoric of Irony, Chicago, University of Chicago Press.

Burn, Stephen J. (ed.) (2012): Conversaciones con David Foster Wallace, traducción al español de José Luis Amores. Málaga, Editorial Pálido Fuego.

De Man, Paul (1996): El concepto de ironía, Valencia, Ediciones Episteme. Traducción al español de Manuel Asensi.

Foster Wallace, David (2008): «E unibus pluram: televisión y narrativa americana», en Algo supuestamente divertido que nunca volveré a hacer. Ensayos y opiniones, traducción al español de Javier Calvo.Mondadori, Barcelona: 33-100. Primera edición de 2001.

Foster Wallace, David (2014): «Algunos comentarios sobre lo gracioso que es Kafka, de los cuales probablemente no he quitado bastante», en Hablemos de langostas, traducción al español de Javier Calvo, Barcelona, Debolsillo, primera edición de 2007: 79-84.

Frye, Northrop (1991): Anatonía de la crítica, traducción al español de Edison Simons, Caracas, Monte Avila, primera edición de 1977.

Garrido Miñambres, Germán (2021): «Estudio introductorio. Caracterización de un crítico», en Schlegel, Friedrich, Cuadernos literarios, Madrid, Akal, 2021: 5-54.

Gerchunoff, Santiago (2019): Ironía On, Barcelona, Anagrama.

Hutcheon, Linda (1994): Irony's Edge: The Theory and Politics of Irony, Londres, Routledge.

Kierkegaard, Søren (2000): De los papeles de alguien que todavía vive. Sobre el concepto de ironía.

Escritos 1, traducción al español de Darío González y Begoña Saez, Madrid, Trotta.

Kundera, Milan (2012): El arte de la novela, Barcelona, Tusquets, primera edición de 1986.

Traducción al español de Fernando Valenzuela y María Victoria Villaverde.

Platón (1992): Diálogos IV: República, traducción y notas de Conrado Eggers Lan, Madrid, Gredos.

Raga Rosaleny, Vicente (2007a): «La ironía socrática como arte de vivir», en Éndoxa: Series Filosóficas, 22, 2007: 69-85. 
Raga Rosaleny, Vicente (2007b): «Schlegel y los enemigos de la ironía romántica», en Anales del Seminario de Historia de la Filosofía, 24: 155-170.

Raga Rosaleny, Vicente (2007c): «Alegoría e ironía: Paul De Man y la ironía posmoderna», en Thémata. Revista de Filosofía, 39: 491-498.

Raga Rosaleny, Vicente (2008): «La ironía se dice de muchas maneras», Daimon. Revista de Filosofía, suplemento 2: 113-120.

Rorty, Richard (2008): Filosofía y futuro, traducción al español de Javier Calvo y Ángela Ackermann Barcelona, Gedisa, primera edición de 2002.

Sánchez Usanos, David (2020): «Error del sistema: hiperadaptación y fracaso en "El neón de siempre”, de David Foster Wallace», Tropelias. Revista de Teoría de la Literatura y Literatura Comparada, 6 (número extraordinario): 104-117

Schlegel, Friedrich (2009): Fragmentos. Seguido de Sobre la incomprensibilidad, traducción al español y notas de Pere Pajerols, Barcelona, Marbot. 


\section{SOBRE LAS AUTORAS}

\section{David Sánchez Usanos}

David Sánchez Usanos es profesor de filosofía en la Universidad Autónoma de Madrid. En el pasado compaginó su labor docente e investigadora con la traducción y la crítica literaria y musical. Entre sus últimas publicaciones destaca el libro $A$ tres versos del final. Filosofía y literatura (Siglo XXI).

\section{Contact information:}

Departamento de Filosofía. Facultad de Filosofía y Letras

Universidad Autónoma de Madrid

Campus de Cantoblanco

28049 Madrid

david.sanchez@uam.es 